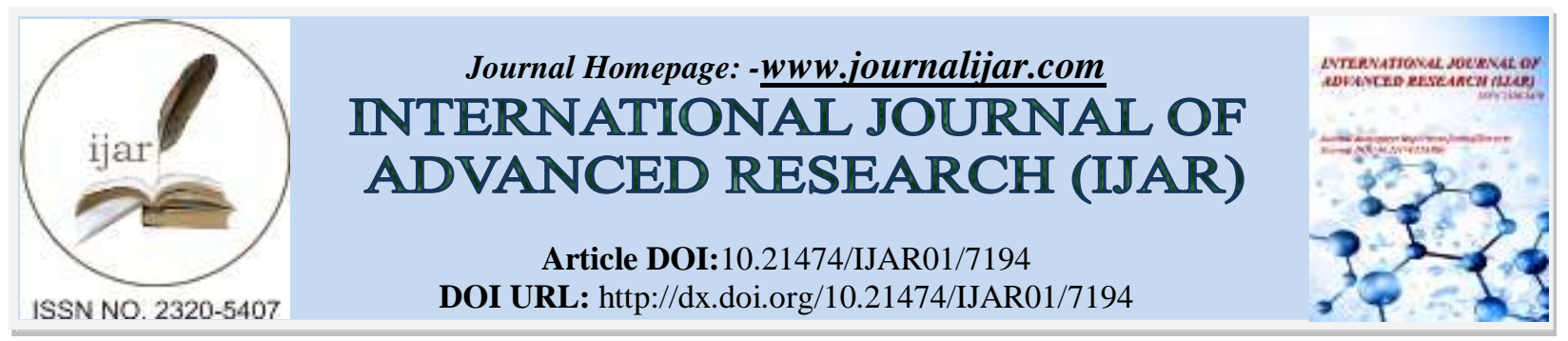

RESEARCH ARTICLE

\title{
CULTURAL GENOCIDE - A GENOCIDAL TECHNIQUE AGAINST CHILDREN: AN UNDERSTANDING THROUGH INTERNATIONAL CRIMINAL JUSTICE SYSTEM.
}

Dr. A. Vijayalakshmi.

Asst Prof (SS), Dept of Criminal Law and Criminal Justice Administration, School of Excellence in Law, The Tamil NaduDr. Ambedkar Law University, Chennai.

\section{Manuscript Info}

Manuscript History

Received: 03 April 2018

Final Accepted: 05 May 2018

Published: June 2018

\section{Keywords:-}

International Humanitarian Law, Genocide, Ad Hoc Tribunals, International Criminal Court, Child Rights, United Nations.

\begin{abstract}
Any violation of human rights under the international humanitarian law is serious crimes under international criminal justice system. Any actions that shocks the conscience of international community will be answered through Chapter VII of the Charter of United Nations, 1945. The sources of international humanitarian law are majorly the Conventions, Declarations, and Covenants etc. In this paper the author going to analysis the application of Convention on Prevention and Punishment of Crime of Genocide, 1948 with specific reference to judicial interpretation on the prohibitory acts of genocide against children. The classical work of Prof Lemkin leads to the introduction of the term genocide to the international community. The author going to analysis the child rights with specific reference to decisions passed the various international tribunals, the International Criminal Court, the contributions of various scholars towards the protection and justifiability of child rights. The protection of human rights has gained the jus cogens status and any such violation is amounts to delictumjusris gentium. The application of protection of human rights internationally is not limited only to adults but also extends to various groups like refugees, war prisoners, children, women, disabled, prisoners etc. in this paper the author going to limit his study to analysis the rights relating to children during armed conflicts. The contributions of ad hoc tribunals, The Rome Statute, Four Geneva Conventions and other international instruments etc are the main sources of the research.
\end{abstract}

Copy Right, IJAR, 2018,. All rights reserved.

\section{Introduction:-}

Child rights or child protection legislation are over flooded nationally and internationally. The question of implementing the rights or protection is a debatable issue for a long time. The consequential effects of the World Wars I and II insisted the need for the reconciliation of human rights violations and international public order. The practices and experiments carried out by the Nazi regime against the international human community shocks the conscience of international human rights supporters. This leads to the comprehensive outlook on the notion of the international crimes (delictum juris gentium-crimes against all nations). Thus, the introduction of international crimes was based on the international response to the human rights violations throughout the world. International crimes are those which destruct the values of humanity wherein it becomes a universal concern. As per the Principle 
of Legality, under criminal jurisprudence is explicit that is nullumcrimen sine lege (no crime without law)and nullumpoena sine lege(no punishment without law). It is mandatory that for the definitional elements, without substantive law substantive justice cannot be rendered. But to the contrary international crimes falls under the categorization of Principle of Substantive Justice and therefore if the crimes or the prohibited acts are of such nature as to violate the general principles of international law, then still it qualifies to be condemned. As a response to such heinous crimes and as a remedial mechanism with the sole objective of maintenance of peace and security, established the United Nations Organizations (herein after referred to as the 'UN/United Nations'). For the further development of international crimes law and International Criminal Law (herein after referred to as the 'ICL'), ad hoc International Criminal Tribunals were established. The object was to prosecute and punish to the perpetrators of the international crimes.

\section{Contemporarydevelopment of International Criminal Law: -}

The first step to make up the ICL was substantive law which includes definition of the prohibited acts of the crimes, accountability, elements and defences. International crimes mean, offences over which international courts or tribunals have been given jurisdiction under public international law. After World War II, the twin international tribunals International Military Tribunal (herein after referred to as the 'IMT') and that of the International Military Tribunal for the Far East (herein after referred to as the 'IMTFE'). The decisions on punishing the Nazis war criminals during 1946, the codification of international crimes commences. Followed by the international Conventions inter alia (a) Convention on the Prevention and Punishment of the Crimes of Genocide, 1948 (herein after referred to as the 'Genocide Convention') ${ }^{1}$, Geneva Convention for the Amelioration of the Conditions of the Wounded and Sick in the Armed Forces, on the High Seas, Protection of Prisoners of War and Civilian Rights in the Field of War, 12 ${ }^{\text {th }}$ August, 1949 and its Additional Protocols (herein after referred to be as the 'Geneva Conventions') marked an advance as regard the extension of the substantive laws or crimes ${ }^{2}$. This Conventions added a new crime called War Crimes, though War Crimes have been prosecuted and punished by the IMT.Any grave breaches of these Geneva Conventions are considered as War Crimes. Another Convention aided for the development of the ICL was the International Convention on the Suppression and Punishment of the Crime of Apartheid, adopted by the UN General Assembly on $30^{\text {th }}$ November $1973^{3}$. This Convention again particularly mentioned in it that, any inhuman acts resulting from the policy of Apartheid are qualified as Crimes against Humanity. The next source of ICL is the Charter of the Nuremberg Charter, $1950^{4}$. After the Genocide Convention, the UN General Assembly (herein after referred to as the 'UNGA') along with the International Law Commission (herein after referred to as the 'ILC') prepared a Statute for International Criminal Jurisdiction (UNGA/Res/216B(II)). ILC is a body of experts who are being nominated by the General Assembly and the major task them is codification and the progressive development of the international law. The crimes established under this Principle are, Crimes against Peace, Crimes against Humanity and War Crimes ${ }^{5}$. The ILC drafted the Code of Crimes against the Peace and Security of Mankind, and submitted the report in 1996 and the Commission recommended the following crimes as international crimes, crime of aggression, crime of Genocide, Crimes against Humanity, crimes against UN and associated personnel and War Crimes ${ }^{6}$. However, the systematic development of the international crimes was evolved by way of the establishment of the two UN sponsored Ad-hoc Tribunals, in details, the Bosnian Genocide in the backdrop of Former Yugoslavia during 1992 and African Genocide in Rwanda during 1994.

\footnotetext{
${ }^{1}$ Adopted by the UN General Assembly through Resolution UNGA/Res/96(1) on December 1948.

${ }^{2}$ The International Committee of Red Cross Sponsored the Geneva Convention for the Protection of war soldiers, wounded and shipwrecked persons, prisoners of war, and wounded and the protection of Civilians. It is a source of international humanitarian law.

${ }^{3}$ This Convention was adopted with the view for the joint and separate action in co-operation with the organisation for the achievement of the Universal respect for and observance of the human rights, fundamental freedom for all without any distinction as to race, sex, language and religion.

${ }^{4}$ Principle IV of the said documents states that, the crimes which are punishable under international law are War Crimes, Crimes against Peace and Crimes against Humanity.

${ }^{5}$ Art. IV of the Charter of the Nuremberg categorised the international crimes by the work of the ILC.

${ }^{6}$ Arts.16 to 20 of the Draft Code of the Crimes against Peace and Security of Mankind gives the detailed interpretation of the crimes. The detailed reports and commentaries on the Draft Code are available at www.internationallawcommission.org accessed on 16.3.18.
} 
The United Nations Security Council (herein after referred to as the 'UNSC') in an unprecedented manner by relying upon the Art.39 of the Chapter VII of the Charter of the Unestablished the twin tribunal called (i) the International Criminal Tribunal for the Former Yugoslavia (herein after referred to as the 'ICTY') and (ii) the International Criminal Tribunal for Rwanda (herein after to as the 'ICTR'). On 1993, through the UNSC/Res/827/1993 it established the ever first Ad-hoc tribunal to prosecute and punish person responsible for serious violations of the International Humanitarian Law (herein after referred to as the 'IHL') committed in the territory of Former Yugoslavia. Under the Statute of the ICTY, the following crimes are being recognised for the prosecution and punishment, (i) grave breaches of Geneva Convention; (ii) violations of laws or customs of war; (iii) Genocide; (iv) Crimes against Humanity. Following this, in 1994, reacting to the request from the permanent representatives of Rwanda, the Security Council established the next Ad-hoc tribunal the ICTR to prosecute the person charged with the crimes of Genocide and other serious violations of IHL by UNSC/Res/955/1994 and the Crimes under the Statute of the ICTR are (i) Genocide; (ii) Crimes against Humanity(herein after referred to as the 'CAH') and (iii) Violations pf Art.3 Common to Four Geneva Conventions, 1948 and Additional Protocols (herein after referred to as the 'War Crimes'). In 1996, the ILC negotiated by the UNGA based on the draft elements of crimes, established a Preparatory Committee to submit its report by drafting a Statute which consists of 116 Articles in 1998 and finally in 2000 as Rome Statute for the Permanent International Criminal Court (herein after referred to as the 'ICC'). The crimes under Art.5 of the Statute of the ICC are as follows, (i) Genocide; (ii) CAH; (iii) War Crimes and (iv) Crime of Aggression. In the contemporary international law, the new dimension on whether the States can commit crimes was first questioned before the International Court of Justice (herein after referred to as the 'ICJ') in the Yugoslavian and Rwandan Genocide, Bosnia and Herzegovina v. Serbia decision. Through these decisions, under Genocide Convention, identifying actus Reus and mens rea for CAH and War Crimes and nonStates Criminal Responsibility has evolved ${ }^{8}$.

\section{Legal Evolution of the International Crime of Genocide: -}

In the pecking order of international crimes, Genocide is extremely alleged as serious, barbaric and gravest of all inhuman acts which are committed against the fellow human. Though the history has witnessed various genocidal events, twentieth century observed the sufferings of this heinous crime from hands of various governments. If we look into the causative factor for such State sponsored atrocities against its own citizens for extermination the answer might be (i) State attempts to purify its own social order; when the inferior group perceived as trouble of a particular State; when a State decides to change the overall structure including socially, economically and politically; when a State prevents the right of self-determination of a particular group; when a State want to promoting a specific culture and; elimination of existing group which are perceived to be threat of the society. The crime was unnamed since the paper submitted by the renowned Polish jurists Prof. Raphael Lemkin in 1944 in his work "Axis Rule in Occupied Europe: Laws of Occupation-Analysis of Government -Proposal for Redress" (herein after referred to as the 'Axis Rule'). He was the instrumental factor who attracted the attention of the international community to take note of the magnitude and the gravity of the offence. He defined the term Genocide which means destruction of a nation or of an ethnic group. The author combined the two terms to denote the old practice in its new development, the ancient Greek term genos which means race or tribe and the Latin term cidemeans killing ${ }^{9}$.

\footnotetext{
${ }^{7}$ Decision Concerning Application of the Convention on the Prevention and Punishment of the Crime of Genocide. (Bosnia and Herzegovina v. Serbia and Montenegro) ICJ Judgement dated 27 February 2007, pp.43. The Full decision is available at www.icj.org/contentiousdecisions accessed on 14.3.18.

${ }^{8}$ Based on the jurisprudence evolved by the ICTY and ICTR, the UNSC also established some tribunals namely Special Tribunal for Sierra Leone to prosecute and punish the crimes such as CAH, War Crimes, serious violations of IHL and crimes under Sierra Leone Criminal Law (UNSC/Res/1315/2000, 14 ${ }^{\text {th }}$ August, 2000); the next was the Special Tribunal for Lebanon to try all those responsible for killing the Prime Minister Rafiq Hariri (UNSC/Res/1595,1644,1757/2006) and this tribunal has the jurisdiction to prosecute the crime of terrorism also; the establishment of Extraordinary Criminal Court for Cambodia considered to be one of the sources of development of ICL and international crimes. This was also called as Khmer Rouge Tribunal to try and punish the persons responsible for committing crimes during the democratic period of Khmer Rouge.

${ }^{9}$ Axis Rule in Occupied Europe was published in November 1944 was the first place where the word "Genocide", appeared in print, though the author of the term in 1943 and submitted in 1993 Madrid Proposal as a analysis of German occupation policy in Europe. He directly addressed the term in his book in Chapter IX of Part I, he broadly used the term not only to describe the systematic extermination of Jews by Germans, but also described a coordinated plan of different action. Part I: Analysis of "German Techniques of Occupation", last chapter discussed about Genocide.
} 
Prof. Lemkin input towards the formation of the term for the crimes, great effort to bring out a legal frame work for the implementation of the prevention and punishment of the crime are worth mentioning. Prof. Lemkin precisely categorised the two phases of Genocide as (i) destruction of national pattern of the oppressed and (ii) imposition of national pattern of the oppressor. The international jurists argued that the application of the age ole terminology "Denationalization" was inadequate as it failed to achieve the complete essence of the definition of the crime ${ }^{10}$. He discussed about the various techniques adopted by the Nazi's to commit the crime of Genocide in the occupied territories, in his treaties inter alia political, social, cultural, economical, biological, physical, religious and moral. Each technique has its own methodology to commit the crime. Cultural genocide includes prohibition of using their language, restriction over education, transferring of children from one group to another and compelled to follow the subsequent group's culture. Under biological genocide, which is one of the most effective modes of destruction of a particular group was handled through "people of non-related blood". To decrease the birth rate of aparticular national group of non-related blood group, marriage with the same group was prohibited, male members were separated from the group, destroyed the particular group without killing ${ }^{11}$.

Prof. Lemkin's role in the Progressive Development of the International Law on Universal Jurisdiction: In 1947 Prof.Lemkin in his celebrated work "Genocide as a Crime under International Law" ${ }^{12}$ he dealt with another facet of the prohibition of Genocide which is the notion of Universal Jurisdiction. With the significance of his work the United Nations Economic and Social Council (herein after referred to as the 'ECOSCO') in brought a proposal into a legal frame work. With the support and sponsoring of the delegates from the Governments of Cuba, Panama, and India ${ }^{13}$ the draft resolution of the treaty was signed and placed before the UNGA. After several modifications and amendments, the ECOSCO submitted its report to the Legal Committee and it was approved and adopted by the UNGA through resolution UNGA/Res/96(1) A, December, $1946^{14}$, now crime of Genocide become the crime under international criminal law.

\section{Role of International Ad-hoc Tribunals in understanding the elements of Crime of Genocide: -}

The UNSC expressed the grave alarm at continuing reports of widespread and deliberate violations of IHL within the territory of the Former Yugoslavia particularly in the territory of Bosnia and Herzegovina. The violations include mass killings, systematic and organised detention, rape of women, continuance of the practice of 'ethnic cleansing' etc. in this regard the UNSC decided to establish an Ad-hoc international criminal tribunal to achieve the restoration and maintenance of peace by acting under Chapter VII of the Charter of UN. The sole purpose of the tribunal is to prosecute and punish the person responsible for serious violations of IHL committed in the territory of Former Yugoslavia between $1^{\text {st }}$ January 1991 and a date to be determined by the UNSC upon the restoration of peace,

\footnotetext{
${ }^{10}$ According to Prof. Lemkin in denationalization is inadequate because it does not connote the destruction of the biological structure, imposition of national pattern of the oppressor and it is used by some authors to mean only deprivation of citizenship.

${ }^{11}$ That the separation of males from females was preconceived by Hitler as an element of Genocide is obvious from his statement: "We are obliged to depopulate", he wants to emphatically, as a part of our mission of preserving the German population. We shall have to develop a technique of depopulation. If you ask me what I mean by depopulation, I mean the removal of entire racial units. And that is what I intended to carry out that roughly, is my task. Nature is cruel; therefore, we too, may be cruel. If I can send the flower of the German nation into the hell of war without the smallest pity for the spilling of precious German blood, then surely, I have the right remove millions of an inferior race that breeds like vermin. And by "remove" I don't necessarily mean destroy; I shall simply take the systematic measures to dam their great natural fertility. For example, I shall keep their men and women separated for years. Do you remember the falling birth rate of the world war? Why should we not do quiet consciously and through many years what was at that time merely the inevitable consequence of the long war? There are many ways, a systematically and comparatively painless, or at any rate bloodless, of causing undesirable races to die out." Axis Rule in Occupied Europe, D.C. Carnegie Endowments for International Peace, (1994), pp. 137-138.

${ }^{12}$ Raphael Lemkin, “Genocide as a Crime under International Law", (1947) Vol.41(1): pp.145-151. The full text of the article is available at www.preventgenocide.org accessed on 19.3.18.

${ }^{13}$ The discussion in the Legal Committee was highlighted by the very learned comments of the following: H. E. Guillermo Belt, Ambassador of Cuba, Hon. Mrs. Vijayalakshmi Pandit, Chairman of the Delegation of India, and H.E. Dr. Ricardo J. Alfaro, Minister of Foreign Affairs of the Republic of Panama, for sponsoring the resolution.

${ }^{14}$ The Preamble of the draft consists definition of the crime which mens rea and actus reus. The next part essentially remarked that Genocide is denial of right of entire human groups as that of the homicide which is the denial of right to live.
} 
through the resolution UNSC/Res/827/1993 dated 25 May, 1993 ${ }^{15}$. The jurisdiction of the ICTY are (i) grave breaches of the Geneva Convention, 1949 (War Crimes; (ii) violations of the laws or customs of war; (iii) Genocide and (iv) $\mathrm{CAH}^{16}$

The United Nations Security Council acted on the letter received from the permanent representatives of Rwanda regarding the hostilities between the Rwandan Government and the Rwandan Patriotic Force. After various deliberations $^{17}$ on 8 November 1994 through the resolution UNSC/Res/955/1994, established the International Criminal Tribunal for Rwanda to prosecute and punish the persons responsible for genocide and other serious violations of IHL. The jurisdiction of ICTR are (i) Genocide; (ii) CAH and (iii) War Crimes ${ }^{18}$.

Definition of Crime of Genocide under the 1948 Convention and the Statutes of the ICTR and the ICTY: Definition of crime of Genocide under the Statutes of the ICTY and the ICTR are the verbatim of the definition under Art. II of the 1948 Genocide Convention, is as follows:

"In the present Convention, Genocide means any of the following acts committed with intent to destroy, in whole or in part, a national, ethnical, racial or religious group, as such:

1. Killing members of the group;

2. Causing serious bodily or mental harm to members of the group;

3. Deliberately inflicting the group conditions of life calculated to bring about its physical destruction in whole or in part;

4. Imposing measures intended to prevent child birth within the group;

5. Forcibly transferring the children of the group to another group" $"$.

From the definition we can classify the techniques of genocide, mental element and material element of the crime. According to the maxim actus non facitreum nisi mens sit rea (nothing is a crime without guilt mind), the first phrase of the Art. II denotes the mental element part. The required mental element in Genocide is special element or intent I,edolusspecialis to destroy, in whole or in part, a national, ethnical, racial or religious group, as such. The second phase of the definition deals with the material element of the crime.

\section{Cultural Genocide as crime against children under International Criminal Law ${ }^{20}$ :-}

The mental elements of the crime of genocide can be classified as physical, biological and cultural genocide. Cultural Genocide exclusively deals with the prohibited acts against children. Though both the tribunal the ICTY and the ICTR haven't pass any decision on the fifth element I,e forcible transfer of children from one group to another, the interpretation of the element given by the tribunals supported the contemporary development of the ICL. As the Trial and Appellate Chambers of the twin tribunal haven't charged any accused for the intent of cultural genocide, it is accepted that forcible transfer of children from one group to another with the intent to destroy in whole or in part any national, ethnic, racial or religious group is considered as genocide. The ICTR Trial Chambers

\footnotetext{
${ }^{15}$ For the first time the UNSC declared that "ethnic cleansing" as also serious violations of IHL. The full text of the resolutions refers www.un.org/en/sc/serach/view_doc.asp?sysbol=S/RES accessed on 13.3.18

${ }^{16}$ Arts. 2,3,4, and 5 of the Statute of the ICTY respectively.

${ }^{17}$ The UNSC in its resolution 812/1993, dated 12 March 1993 called for cease fire, return of displaced person. UNSC/Res/872/1993 dated 5 October 1993, the Security Council urged the parties to the dispute to deploy natural forces in Rwanda and extended its support by way of establishing UNAMIR. On 21 April 1994, the UNSC expressed its regret in resolution UNSC/Res/912/1994, over large-scale violence which includes killing of considerable number of women, children and elderly person in Rwanda after the assassination of the Prime minister. UNSC/Res/927/1994, dated 8 June 1994, the UNSC declared that genocide have occurred in Rwanda.

${ }^{18}$ Arts. 2,3,4 of the Statute of the ICTR.

${ }^{19}$ UNGA Resolution 260A(III) December 1948.

${ }^{20}$ Nehemiah Robinson in his commentary on The Genocide Convention referred in Appendix IV about the Draft Convention prepared by the Ad-hoc Committee, noted that killing, causing serious bodily or mental harm and deliberately inflicting the condition of the group are considered to be PHYSICAL; preventing child birth within the group as BIOLOGICAL GENOCIDE and forcible transfer of children to another group as CULTURAL GENOCIDE.
} 
in The Prosecutor v. Jean Paul Akayesu ${ }^{21}$ has opined that acts or trauma which would lead to the forcible transfer of children from one group to another group may falls within the cultural genocide. The problem is about to determine the liability of forcibly transferring grown children might have not fulfil the essence of Art. 2 (2)(e) of the Statute of the ICTR. When the children transferred to another group, they could not grow up as part of their group, or they became estranged from their cultural identity. The language, tradition and culture of the group became alien to them.

The United Nations Convention on the Rights of Child, 1989 (herein after referred to as the 'CRC'), was adopted by the UNGA with the objective to provide full and harmonious development of the child with the family atmosphere. In addition to that the CRC also stressed the need for individual life in the society; in particular develop the child in the spirit of peace, dignity, tolerance, freedom, equality and solidarity. The strict indication is made in the Convention that because of physical or mental immaturity the child should be safeguarded through proper legal framework before and after birth by the State. The Convention again stressed the importance of the traditions and cultural values of each child ${ }^{22}$. The Commentaries on the Convention by the UNICEF ${ }^{23}$ in particular to the registration of birth, right to nationality, preservation of identity, nationality including name and family relations without unlawful interference, not to be separated from the parents against their will and if there is any such separation in the form of deportation, detention, the State should act accordingly, family reunifications, illicit transfer and non-return of child from abroad ${ }^{24}$, discussed about the implementation of the rights guaranteed by the Convention.

In particular, Arts.9 and 11 of the $\mathrm{CRC}$ has the relevance of the fifth element of definition of crime of Genocide and the Statutes of the ICTY and the ICTR. It became the duty of the State to protect the right of every child against unlawful separation from the parents. The State shall ensure that child shall not be separated from the parents except on judicial review and for the best interest of the child. If the child has been separated from their parents, the State shall take steps to maintain the personal relations and direct contact with the parents. If the separation is based on any imprisonment, detention, deportation, the State shall determine such action by keeping in mind the wellbeing of the child, request the authorities concerned to provide information to the family members.

The International Covenant on Civil and Political Rights, 1966 (herein after referred to as the 'ICCPR'), enshrined that the family is the natural and fundamental unit of the society, which is entitled for protection from the hands of the State ${ }^{25}$, which again stressed in the International Covenant on Social, Economic and Cultural Rights, 1966 (herein after referred to as the 'ICSECR'). It is read as 'No one shall be subjected to arbitrary or unlawful interference with his privacy, family, home or correspondence, or to unlawful attacks on his honor and reputation. Everyone has the right to the protection of the law against such interference or attacks" ${ }^{26}$.

Art.11 of the CRC deals with the illicit trafficking of children and their non-transfer. To prevent and prohibits such trafficking through multilateral agreements or accession to the existing treaties. The drafting committee of the CRC also referred the jurisdictional issues involved in such trafficking. The interpretation of Art.11 by the UNICEF in the commentary is that the said action is equivalent to "abduction". To support the view, the drafters referred The Hague Convention on the Civil Aspects of International Child Abduction, 2007, protect the children from wrongful transfer and retained in foreign country. To enforce such treaty on child abduction, the Committee also referred the Regional Treaty such as Inter-American Convention on the International Return of Children, and the European Convention on the Recognition and Enforcement of Decisions Concerning Custody of Children. Though this Art.11 does not

\footnotetext{
${ }^{21}$ The Prosecutor v. Jean Paul Akayesu ICTR Decision No: ICTR-96-4-T, judgement dated 2 September 1998. This was the first decision passed by the tribunal invoking the 1948 Genocide Convention and convicted the accused for the crime of Genocide.

${ }^{22}$ The United Nations General Assembly with the objective to protect and develop the rights of every child through resolution UNGA/Res/45/25 dated $20^{\text {th }}$ November 1989, which come into on 2 September 1989 . The full text of the Convention is available at www.ochr.org/Documents/ProfessionalInterest/crc.pdf accessed on 29.3.18.

${ }^{23}$ Implementation Handbook for the Convention on the Right of Child, (Fully revised third edition), UNICEF, 2007, Switzerland, pp: 97-144.The full version available at https://www.unicef.org/publications/files/Implementation_Handbook_for_the_Convention_on_the_Rights_of_the_ Child_Part_1_of_3.pdf accessed on 29.3.18

${ }^{24}$ Arts. $7,8,9$ and 11 of the Convention.

${ }^{25}$ Art.23(1) of the International Covenant on Civil and Political Rights.

${ }^{26}$ Arts. 10 and 17(1)(2) of the International Covenant on the Social, Economic and Cultural Rights.
} 
directly deals with the illegal abduction, but it imposes the responsibility on the State to prevent and prohibit such act under the doctrine of parens triae (A doctrine that grants the inherent power and authority of the state to protect persons who arelegally unable to act $\mathrm{o}$ $\mathrm{n}$ their own behalf). The Convention also imposed an obligation on the parties to the treaty to ratify this particular provision.

From the above discussion, the substances are the rights which are being guaranteed by the International Organisation through International Instruments. According to the opinion of international criminal law scholars like William A. Schabas, Cherif M. Bassioni, the sources of International Humanitarian Law are international instruments which protect the rights of every citizens of the international community at large during the time of war. To the contrary, the sources of International Human Rights Law (herein after referred to as the 'IHrL') are the instruments which protect the rights of every one either during peace or war inter alia Genocide Convention 1948, Child Rights Convention 1989, Convention on Elimination of Discriminations Against Women, Slavery Convention, Convention on Apartheid etc..

Any violation of said rights protected under the IHL or the international human rights law are international crimes. The Four Geneva Conventions 12 August 1949, and its Additional Protocols I and II, 1977 which speaks about the protection of rights during internal and international armed conflicts. Henceforth, we are in the contemporary era of international criminal justice system. Through interpretations given by the international criminal forums for the violations of any of the protected rights under the IHL or IHrL were considered as international crimes accordingly. For eg: the second element of the definition of crime of Genocide, "causing serious bodily or mental harm" was interpreted by the ICTR Trial Chambers in such way that rape also amount to causing serious bodily or mental harm $^{27}$. In the Trial Chambers of the ICTY interpreted the intent of causing serious bodily and mental harm was made in the context of survivors. In The Prosecutor v. VidojeBlagojevic and Dragon Jokic ${ }^{28}$ the Chamber interpreted in terms of victimological sense, the construction placed on the foundational approach in characterization the different sufferings and plight undergone by the victims of genocide. Along with that, forcible transfer and disposition of the victims also fall under the category of causing serious bodily or mental harm to the members of the group.

The interpretation of the said definition of the crime of Genocide and other international crimes by the international tribunals leads to the establishment of the ICC in the year 2000. Even after still the armed conflicts either internal or international in nature is occurring some parts of the world. Armed conflicts in Syria, Israel, Iran and Iraq, Sri Lanka etc. The International organisation are considering any attack against children as War crimes but not as crime of Genocide. Without any precedent, this element needs the attention of the international criminal justice system to seek the proper justice. The special intention of the perpetrators of the crime either may be the individual or the State should be prosecuted or punished. As in 2015, the ICJ declared that it is the responsibility of the State for wrongful acts under Art. 10(2) of the ILC Articles on State Responsibility ${ }^{29}$, though the Court rejected the plea of Croatia to impose the liability on Serbia for its failure to prevent the crime of Genocide, but the acceptance of the case itself determine that State may be also be held liable for any such serious violations of IHL or IHrL.

In the above circumstances, it is the need of the hour to interpret the elements of crime of genocide by invoking the jurisprudence evolved by the international Ad-hoc and ICC more extensively. In the current scenario in any armed conflict (internal or international), the targeted groups are women and children those who are disadvantaged or vulnerable. Any violation of human or humanitarian rights shall be addressed as delictum juris gentium. The crime

\footnotetext{
${ }^{27}$ The Prosecutor v. Jean Paul Akayesu, ICTR judgement dated 2 September 1998, para. 731 reads as sexual violence was an integral part of the process of destruction, specifically targeting Tutsi women and specifically contributing to their destruction and to the destruction of the Tutsi group as a whole. Further it was held that the destructive psychological effects of crimes of sexual violence are much graver when compared to physical hostilities. The same preposition was followed in The Prosecutor v. Juvenal Kajilijeli as the harm inflicted must be objectively capable of contributing to the destruction of the group, ICTR judgement No: ICTR-98-44-A-T, dated 1 December, 2003, para. 814.

${ }^{28}$ The Prosecutor v. VidojeBlaogojevic and Dragon Jokic, ICTY Decision No: IT-02-60-T dated 17 January, 2005, paras. 645-648.

${ }^{29}$ Case Concerning the Application of the Convention on the Prevention and Punishment of Crime of Genocide (Croatia v. Serbia), 3, September, 2015.
} 
against children under international criminal should be given with jus cogens (peremptory norms-compelling necessity)status and it shall be the ergaomnes(implementing obligations on the State parties). The techniques which were introduced and discussed by the founder of the crime Prof. Lemkin shall be apply with due consideration by the international criminal system.

\section{Conclusion:-}

According to Art. II (2)(e) of the 1948 Genocide Convention, the cultural genocide should be addressed properly and cautiously. In every violation of human rights against children under international criminal law shall be prosecuted and punished without any immunity.Any transfer during armed conflict or peace is violation under Geneva Conventions, Child Rights Convention, Hague Convention on Child Abduction. The protection guaranteed under the international instruments shall be considered as the sources of IHL irrespective of the circumstances of the commission. Children should not be the targeted group or oppressed group in any event. As crime of Genocide was considered as Crime of Crimes as it stands high in the hierarchy of international crimes. Though there is no such ranking among the international crimes, the gravity and intensity of the crime placed it as highest one. Hence the author extensively and ardently discussed on crime of genocide against children, which is still in grey area. Transferring of children should not be considered as either forcible displacement or enforced disappearance, but only as material element of genocide. The prosecution should prove the mental element of the perpetrator of the crime that such transfer shall not be considered as either CAH or War Crimes, but only crime of Genocide due to it special element (dolusspecialis). The day when the ICC or any other special Criminal Tribunal pass any decision on such interpretation, will be a breakthrough in the development of international criminal law into next level. 